\title{
'Vermillion' Sweetpotato
}

\author{
Don R. La Bonte \\ Louisiana Agricultural Experiment Station, Louisiana State University \\ Agricultural Center, School of Plant, Environmental, and Soil Sciences, 104 \\ Sturgis Hall, Baton Rouge, LA 70803

\section{Christopher A. Clark \\ Department of Plant Pathology and Crop Physiology, Louisiana State University Agricultural Center, 302 Life Sciences Building, Baton Rouge, LA 70803}

\author{
Tara P. Smith \\ Central Region, Louisiana State University Agricultural Center, 8208 \\ Tom Bowman Drive, Alexandria, LA 71302
}

\section{Arthur Q. Villordon}

Sweet Potato Research Station, Louisiana State University Agricultural Center, P.O. Box 120, Chase, LA 71324

\section{Scott Stoddard}

University of California Cooperative Extension, 2145 Wardrobe Avenue, Merced, CA 95340

Additional index words. vegetable breeding, disease resistance, cultivar

'Vermillion' sweetpotato [Ipomoea batatas (L.) Lam.] was developed by the Louisiana Agricultural Experiment Station to provide an orange-flesh, deep-red-purple-skin cultivar with superior storage root shape, skin smoothness, disease resistance to Fusarium wilt, and excellent storage qualities. 'Vermillion' is average in production beds with proper presprouting. It can be harvested up to $10 \mathrm{~d}$ earlier than 'Covington' (Yencho et al., 2008) and is similar to 'Diane' (Stoddard et al., 2013) in the California production region. 'Vermillion' and 'Orleans' (LaBonte et al., 2012) are similar in harvest days in the Gulf South production region. The roots are elliptical to ovoid and are consistent in shape in varied soil types. 'Vermillion' has a superior shape without lobing, and yields are equal to 'Orleans' for the U.S. \#1 grade $(5.1-8.9 \mathrm{~cm}$ in diameter, 7.6$22.9 \mathrm{~cm}$ long) in California and in the Gulf South production regions. Yield is $15 \%$ less for total marketable yield (U.S. \#1; canner: 2.5-5.1 cm diameter, 5.1-17.8 cm long; jumbo: larger than U.S. \#1 in diameter or length or both, and without objectionable defects) in comparison

Received for publication 4 May 2021. Accepted for publication 3 June 2021.

Published online 12 July 2021

Supported by state and matching funds allocated to the Louisiana State University Agricultural Center and the Louisiana Sweet Potato Advertising and Development Commission. This project was also supported by Hatch funds from the U.S. Department of Agriculture National Institute of Food and Agriculture.

Approved for publication by the Director of the Louisiana Agricultural Experiment Station as manuscript no. 2021-306-35497.

D.R.L.B. is the corresponding author. E-mail: dlabonte@agcenter.1su.edu.

This is an open access article distributed under the CC BY-NC-ND license (https://creativecommons. org/licenses/by-nc-nd/4.0/). with 'Diane' in California. However, 'Vermillion' is superior to 'Diane' in root shape, skin color retention, and length of storage season. The skin of 'Vermillion' is very smooth, and lenticels, eyes, or fine root hairs do not affect its appearance. 'Vermillion' is susceptible to southern root-knot nematode Meloidogyne incognita, but is well suited to sandy soils typical for the production area in California and in silt-loam soils of the Gulf South.

Initially identified and evaluated as 'LA1381 ', the cultivar is named for a parish in Louisiana and in recognition of the skin color.

\section{Origin}

'Vermillion' was first grown in 2013 and originated from an open-pollinated polycross nursery consisting of 17 lines in 2013 and was tested under the line designation 'LA1381'. The female lineage is 'Bonita' (LaBonte et al., 2011) from the Louisiana State University AgCenter Sweetpotato Breeding Program. The male parent is unknown.

\section{Description}

One of the unique characteristics of 'Vermillion' is its thick red-purple storage root skin, which contrasts sharply to most commercial cultivars grown in the United States. 'Diane', in contrast, has red skin without a purple hue. Skin thickness is such that minor scrapes do not expose the lighter orange color of the root cortex. Fast-growing, unfolded immature leaves are purple, corresponding to color charts as [5 P (purple) (2/6)] (Munsell ${ }^{\circledR}$ Color, New Windsor, NY). The numerical and letter designation for color represents the hue; the fraction represents value or chroma. Comparisons between plant tissues and color chips were made in natural light. Mature leaves transition nominally over one to two nodes from the apex to green $[2.5 \mathrm{G}$ (green) Y (yellow) (4/6)] for the adaxial surface. The abaxial surface is lighter green [5 G (green) Y (yellow) (4/2)]. Mature leaves five nodes from the apex had an acute apex and mostly a cordate base, and an entire leaf margin. Some leaves are shallow tricuspid. Mature leaves are similar in size to that of 'Beauregard' (Rolston et al., 1987), 'Orleans', and 'Covington'. The petioles are green $[2.5$ (green) Y (yellow) (5/6)] with a red-purple [5 R (red) $\mathrm{P}$ (purple) (2/6)] marking at the base of the leaf junction with the petiole. The dormant nodal meristem has a slight red-purple marking [5 R (red) P (purple) $(4 / 10)]$ that appears redder than the base of the leaf junction. Leaves of 'Diane' are deeply palmate. The 'Vermillion' canopy biomass is similar to 'Orleans' and 'Beauregard'.

A typical inflorescence of 'Vermillion' has one cluster of three to five flowers per peduncle. Individual flowers are about $3 \mathrm{~cm}$ long from the base of the calyx, and the corolla is $3 \mathrm{~cm}$ wide at the opening. The inner and outer limbs of the corolla (corolla's outermost area, distal from the calyx) are light purple [10 P (purple) (7/4)]. Stigmata appear light purple $[7.5 \mathrm{R}$ (red) $\mathrm{P}$ (purple) (8/4)]. The five stamens are inferior to stigmata and are attached to the ovary.

Storage roots are round-elliptical without lobing and are consistent in shape. In California, the shape is superior to 'Diane', which typically grows long. In trials in 2020, the root length-to-diameter ratio (Bryan et al., 2003) for 'Vermillion' ranged from 2.7 to 3.1 and was statistically similar to 'Covington' and 'Bellevue' (LaBonte et al., 2015). In comparison, 'Diane' had a ratio of 3.3. The skin is red-purple [7.5 R (red) P (purple) (3/8)]. The 'Vermillion' cortex is $3.3 \mathrm{~mm}$ in depth. The flesh of 'Vermillion' is uniformly orange [5 Y (yellow) R (red) (7/14)] and similar to 'Orleans'.

\section{Disease Reactions}

'Vermillion' was compared with 'Orleans' in controlled tests for resistance to common pathogens affecting sweetpotatoes. It was slightly more resistant than 'Orleans' (intermediate to resistant) for soil rot caused by Streptomyces ipomoeae (Person \& W.J. Martin, Waksman \& Henrici). 'Vermillion' and 'Orleans' were resistant to Fusarium wilt or stem rot caused by Fusarium oxysporum Schlect. f. sp. batatas race 0 (Wollenw.) Snyd. \& Hans., but were not tested with race 1 , which occurs in California. 'Vermillion' and 'Orleans' were susceptible to race 3 of southern root-knot nematode Meloidogyne incognita (Kofoid \& White, 1919). 'Vermillion' was intermediate and 'Orleans' susceptible to bacterial soft rot in storage roots caused by Dickeya dadantii Samson et al. (=Erwinia chrysanthemi Burkholder, McFadden \& Dimock). 'Vermillion' was intermediate and 'Orleans' was resistant in reaction to Rhizopus soft rot caused by Rhizopus stolonifer (Ehr. ex. Fr.) Lind. Russet crack symptoms have not been observed in California. 


\section{Insect Resistance}

'Vermillion' is currently being evaluated for relative insect resistance. It ranked lower in banded cucumber beetle damage (Diabrotica balteata LeConte) in comparison with 'Orleans' in 2017 and 2018 replicated trials at Alexandria, LA. There was also less damage from the sweetpotato weevil, Cylas formicarius elegantulus (Summers), in comparison with 'Orleans', was and similar in percentage of uninjured roots to 'Murasaki-29' (LaBonte et al., 2008), a resistant check variety (Chen et al., 2019) (data not shown). 'Vermillion' has not demonstrated any unusual propensity for insect damage in numerous on-farm trials in the Gulf South or in replicated on-farm trials in California.

\section{Production}

'Vermillion' plant production from propagation beds is slightly less, numerically, than 'Beauregard' or 'Orleans'. In California, plant production is greater and more uniform than 'Covington' and slightly less in comparison with 'Diane'.

'Vermillion' was compared with 'Orleans' and 'Diane' (California only) in randomized complete block trials with three or four replications at various locations in Arkansas, South Carolina, Louisiana, and California. Trials covered a range of planting dates and growing days (mostly 122-174 d). 'Vermillion' had U.S. \#1 yields comparable to 'Orleans' in eight trials, and exceeded 'Orleans' in two trials in California (Table 1). Gulf and mid-South trials in 2015 demonstrated similar yield in four trials for U.S. \#1 grade (data not shown); similar results were found in 2016. In replicated on-farm trials in California $(\mathrm{n}=13)$, 'Vermillion' has, overall, demonstrated $\approx 10 \%$ less U.S. \#1 yield and $\approx 15 \%$ less total marketable yield in comparison with 'Diane' (Table 1), the current red-skin cultivar grown predominantly in California. However, marketable yield in long-term stored product is improved over 'Diane' as occurrence of storage rot is less, and color (skin and flesh) decline is more gradual. In California, 4-month storage loss was $7.7 \%$ and $12.6 \%$ for 'Vermillion' and 'Diane', respectively. Total marketable yield performance is reflective of the U.S. \#1 grade in comparison with the other two cultivars (Table 1); rank varies among the three cultivars for canner and jumbo grades (Table 1). Replicated plots have shown 'Vermillion' to have consistent yields for mid- and late-season plantings. Yield declines appeared within norms in poor environments. 'Vermillion' has harvestable roots $\approx 120 \mathrm{~d}$ after planting in most production areas, which is the typical development time for sweetpotatoes and is comparable to 'Orleans' and 'Diane'. Performance is best in sandy soils; however, shape is well maintained in heavier clay soils. Storage quality is excellent; roots are sound and marketable after 6 to 8 months of storage.

\section{Quality Attributes}

'Vermillion', 'Orleans', and 'Diane' roots stored for 5 months in 2018 were characterized

Table 1. Yield by grade of 'Vermillion', 'Orleans', and 'Diane' in replicated trials.

\begin{tabular}{|c|c|c|c|c|}
\hline \multirow[b]{2}{*}{ Cultivar } & \multicolumn{4}{|c|}{ Avg yield $(\mathrm{Mt} / \mathrm{ha})^{\mathrm{z}}$} \\
\hline & U.S. \#1 & Canner & Jumbo & $\begin{array}{c}\text { Total } \\
\text { marketable }\end{array}$ \\
\hline \multicolumn{5}{|c|}{ 2016: Forest, LA; midseason ${ }^{y}$} \\
\hline Vermillion & $22.1 \mathrm{a}$ & $11.0 \mathrm{a}$ & $1.3 \mathrm{a}$ & $34.4 \mathrm{a}$ \\
\hline Orleans & $22.4 \mathrm{a}$ & $13.8 \mathrm{a}$ & $7.7 \mathrm{a}$ & $43.8 \mathrm{a}$ \\
\hline \multicolumn{5}{|c|}{ 2016: Livingston, CA; midseason } \\
\hline Vermillion & $26.6 \mathrm{a}$ & $9.8 \mathrm{a}$ & $15.8 \mathrm{a}$ & $52.2 \mathrm{ab}$ \\
\hline Orleans & $29.1 \mathrm{a}$ & $7.8 \mathrm{~b}$ & $11.0 \mathrm{~b}$ & $47.8 \mathrm{~b}$ \\
\hline Diane & $38.2 \mathrm{~b}$ & $8.2 \mathrm{ab}$ & $13.0 \mathrm{ab}$ & $59.5 \mathrm{a}$ \\
\hline \multicolumn{5}{|c|}{ 2017: Senatobia, MS; midseason } \\
\hline Vermillion & $58.5 \mathrm{a}$ & $21.2 \mathrm{a}$ & $0.0 \mathrm{a}$ & $79.5 \mathrm{a}$ \\
\hline Orleans & $32.3 \mathrm{a}$ & $16.9 \mathrm{a}$ & $4.2 \mathrm{a}$ & $52.2 \mathrm{~b}$ \\
\hline \multicolumn{5}{|c|}{ 2017: Wynne, AR; late season ${ }^{y}$} \\
\hline Vermillion & $23.5 \mathrm{a}$ & $20.5 \mathrm{a}$ & $4.3 \mathrm{a}$ & $48.2 \mathrm{a}$ \\
\hline Orleans & $24.4 \mathrm{a}$ & $10.8 \mathrm{a}$ & $26.2 \mathrm{~b}$ & $61.4 \mathrm{~b}$ \\
\hline \multicolumn{5}{|c|}{ 2017; Windsor, SC; midseason } \\
\hline Vermillion & $35.0 \mathrm{a}$ & $10.7 \mathrm{a}$ & $0.0 \mathrm{a}$ & $45.7 \mathrm{a}$ \\
\hline Orleans & $29.9 \mathrm{a}$ & $24.3 \mathrm{a}$ & $0.0 \mathrm{a}$ & $54.1 \mathrm{a}$ \\
\hline \multicolumn{5}{|c|}{ 2017: Livingston, CA; midseason } \\
\hline Vermillion & $29.5 \mathrm{a}$ & $8.8 \mathrm{a}$ & $7.0 \mathrm{~b}$ & $45.3 \mathrm{a}$ \\
\hline Orleans & $31.1 \mathrm{a}$ & $9.5 \mathrm{a}$ & $10.1 \mathrm{a}$ & $50.6 \mathrm{a}$ \\
\hline Diane & $31.5 \mathrm{a}$ & $9.1 \mathrm{a}$ & $9.9 \mathrm{a}$ & $50.5 \mathrm{a}$ \\
\hline \multicolumn{5}{|c|}{ 2018: Livingston, CA; midseason } \\
\hline Vermillion & $13.2 \mathrm{~b}$ & $8.0 \mathrm{~b}$ & $3.3 \mathrm{a}$ & $24.6 \mathrm{~b}$ \\
\hline Orleans & $17.3 \mathrm{ab}$ & $8.5 \mathrm{~b}$ & $4.0 \mathrm{a}$ & $29.9 \mathrm{a}$ \\
\hline Diane & $20.9 \mathrm{a}$ & $12.8 \mathrm{a}$ & $3.5 \mathrm{a}$ & $37.2 \mathrm{a}$ \\
\hline \multicolumn{5}{|c|}{ 2019: Wynne, AR; late season } \\
\hline Vermillion & $31.9 \mathrm{a}$ & $32.8 \mathrm{a}$ & $5.4 \mathrm{~b}$ & $70.0 \mathrm{a}$ \\
\hline Orleans & $34.5 \mathrm{a}$ & $17.0 \mathrm{a}$ & $22.6 \mathrm{a}$ & $75.3 \mathrm{a}$ \\
\hline \multicolumn{5}{|c|}{ 2019: Livingston, CA; midseason } \\
\hline Vermillion & $29.2 \mathrm{a}$ & $10.7 \mathrm{~b}$ & $5.2 \mathrm{a}$ & $45.1 \mathrm{~b}$ \\
\hline Orleans & $26.0 \mathrm{~b}$ & $9.0 \mathrm{~b}$ & $4.7 \mathrm{a}$ & $39.7 \mathrm{~b}$ \\
\hline Diane & $32.1 \mathrm{a}$ & $13.6 \mathrm{a}$ & $6.4 \mathrm{a}$ & $52.1 \mathrm{a}$ \\
\hline \multicolumn{5}{|c|}{ 2020: Livingston, CA; late season } \\
\hline Vermillion & $24.2 \mathrm{~b}$ & $11.1 \mathrm{a}$ & $2.9 \mathrm{a}$ & $38.2 \mathrm{~b}$ \\
\hline Orleans & $19.2 \mathrm{c}$ & $8.2 \mathrm{~b}$ & $4.9 \mathrm{a}$ & $32.3 \mathrm{~b}$ \\
\hline Diane & $30.2 \mathrm{a}$ & $11.8 \mathrm{a}$ & $5.2 \mathrm{a}$ & $47.2 \mathrm{a}$ \\
\hline
\end{tabular}

${ }^{\mathrm{z}}$ Sizes of roots: U.S. \#1, 5.1 to $8.9 \mathrm{~cm}$ in diameter and 7.6 to $22.9 \mathrm{~cm}$ long; canner, 2.5 to $5.1 \mathrm{~cm}$ in diameter and 5.1 to $17.8 \mathrm{~cm}$ long; jumbo, larger than U.S. \#1 in diameter or length or both, and without objectionable defects. ${ }^{\mathrm{y}}$ Midseason plantings, 16 May through 30 May; late season plantings, 1 June into July.

Values within the same column followed by the same letter are not significantly different at $P=0.05$. Means separation by Duncan's multiple range test.

for nutritional content by Microbac Laboratories, Inc. (Warrendale, PA). The analyzed sample consisted of three randomly selected roots per cultivar. Total carbohydrates for 'Vermillion' $\left(16.8 \mathrm{~g} \cdot 100 \mathrm{~g}^{-1}\right)$ were similar to 'Orleans' and 'Diane' on a fresh weight basis (FWB). Dietary fiber was $1.48 \mathrm{~g} \cdot 100 \mathrm{~g}^{-1} \mathrm{FWB}$ in comparison with 'Orleans' at $1.10 \mathrm{~g} \cdot 100 \mathrm{~g}^{-1} \mathrm{FWB}$, and 'Diane' at $1.69 \mathrm{~g} \cdot 100 \mathrm{~g}^{-1}$ FWB. Calcium was higher and similar to 'Diane' at $30.5 \mathrm{mg} \cdot 100$ $\mathrm{g}^{-1}$ FWB in comparison with 'Orleans' at 11.5 $\mathrm{mg} \cdot 100 \mathrm{~g}^{-1}$ FWB. Levels of vitamin C (12.9 $\mathrm{mg} \cdot 100 \mathrm{~g}^{-1}$ FWB) were similar for 'Vermillion' and 'Orleans', but were less in Diane (8.4 $\left.\mathrm{mg} \cdot 100 \mathrm{~g}^{-1} \mathrm{FWB}\right)$. Potassium was higher in 'Diane' (401 mg. $100 \mathrm{~g}^{-1} \mathrm{FWB}$ ) in comparison with 'Vermillion' and 'Orleans' (270 mg.100 $\mathrm{g}^{-1} \mathrm{FWB}$ ). Total vitamin A in retinol activity equivalents (RAE) was less in 'Vermillion' (266 $\mu \mathrm{g} / \mathrm{RAE} 100 \mathrm{~g}$ FWB) in comparison with 'Orleans' (316 $\mu \mathrm{g} / \mathrm{RAE} 100 \mathrm{~g}$ FWB) and 'Diane' (346 $\mu \mathrm{g} / \mathrm{RAE} 100 \mathrm{~g}$ FWB). Dry matter content was $19.1 \%$ for 'Vermillion' and 'Diane', and $20.2 \%$ for 'Orleans'.

\section{Availability}

Limited quantities of foundation seed (root) stock will be commercially available for the 2022 crop season. Requests for roots should be made to the Sweet Potato Research Station, P.O. Box 120, Chase, LA 71324, or through a licensed certified seed grower. Protected under U.S. Plant Patent 32021 and European Union Community Plant Variety Right grant number EU 57954.

\section{Literature Cited}

Bryan, A.D., J.R. Schultheis, Z. Pesic-VanEsbroeck, and G.C. Yencho. 2003. Cultivar decline in sweetpotato: II. Impact of virus infection on yield and storage root quality in 'Beauregard' and 'Hernandez'. J. Amer. Soc. Hort. Sci. 128:856-863.

Chen, J., M.J. Stout, J. Beuzelin, T.P. Smith, D. LaBonte, J.M. Murray, and J.A. Davis. 2019. Host preference of sweetpotato weevil, Cylas formicarius elegantulus (Summers): An example of Hopkins' host-selection principle. Arthropod-Plant Interact., doi: 10.1007/s11829-019-09704-0.

LaBonte, D.R., C.A. Clark, T.P. Smith, and A.Q. Villordon. 2011. 'Bonita' sweetpotato. HortScience 46:1-2.

LaBonte, D.R., C.A. Clark, T.P. Smith, and A.Q. Villordon. 2012. 'Orleans' sweetpotato. HortScience 47:1817-1818.

La Bonte, D.R., C.A. Clark, A.Q. Villordon, P.W. Wilson, and C.S. Stoddard. 2008. 'Murasaki'29 sweetpotato. HortScience 43:1895-1896. 
La Bonte, D.R., C.A. Clark, A.Q. Villordon, P.W. Wilson, and C.S. Stoddard. 2015. 'Bellevue' sweetpotato. HortScience 50:930-931.

Rolston, L.H., C.A. Clark, J.M. Cannon, W.M. Randle, E.G. Riley, P.W. Wilson, and M.L.
Robbins. 1987. 'Beauregard' sweet potato. HortScience 22:1338-1339.

Stoddard, C., C. Davis, and M. Campbell. 2013.

Sweetpotato production in California. UC ANR. 7237. <http://anrcatalog.ucanr.edu >.
Yencho, G.C., K.V. Pecota, J.R. Schultheis, Z.P. VanEsbroeck, G.J. Holmes, B.E. Little, A.C. Thornton, and V.D. Truong. 2008. 'Covington' sweetpotato. HortScience 43:19111914. 